Центр воєнно-стратегічних досліджень Національного університету оборони України імені Івана Черняховського, Київ

\title{
Обгрунтування врахування життсвого циклу зразків ОВТ під час оборонного планування на основі спроможностей
}

Резюме. У статті розкривається поточний стан та основні недоліки впровадження процесу оборонного планування на основі спроможностей в Збройних Силах України, основні стадії створення нових (модернізації існуючих) зразків озброєння та військової техніки, а також обгрунтовується необхідність урахування життєвого циклу перспективного зразка озброєння та військової техніки під час оборонного планування на середньо- та довгострокову перспективи.

Ключові слова: оборонне планування на основі спроможностей; спроможність; носії спроможностей; стадії життєвого циклу; зразок озброєння та військової техніки.

Постановка проблеми. Зміни та ускладнення у воєнно-політичних відносинах, які відбуваються у світі, призводять до нестійкого стану безпекового середовища як на глобальному рівні, так і у середині України. Рівень агресії, непорозумінь і “перетягування” гілки першості в управлінні світовими ресурсами та оснащеності найсучаснішою високоточною зброєю, а також стрімкий розвиток науково-технічного прогресу, спонукає до перегляду концептуальних поглядів на форми та способи ведення бойових дій, порядок оцінювання наявних спроможностей складових сил оборони та планування їх перспективного розвитку, переоснащення сучасними та технологічними зразками озброєння та військової техніки, ефективність якої відповідала б реальним умовам застосування, можливостям державної економіки, імовірним сценаріям розвитку кризових ситуацій як на сході України, так і у воєнно-політичних відносинах 3 іншими суміжними країнами, а також обраному шляху перспективного інтегрування в світову спільноту колективної безпеки НАТО.

Аналіз останніх досліджень i публікацій. Проведений аналіз останніх наукових досліджень [1-5] 3 питань планування в оборонній сфері показав, що існуюча система оборонного планування, як складова системи стратегічного планування та управління оборонними ресурсами держави, не достатньо відповідає існуючим викликам, які постали перед Україною починаючи 3 розпаду Радянського Союзу та ускладнились у 2014 році внаслідок збройної агресії з боку Російської Федерації.

Серед найбільш вагомих проблемних питань, які потребують термінового вирішення, виділяють: невідповідність процедури оборонного планування сучасним загрозам і викликам, які мають неоднозначний гібридний характер; низький рівень кореляції запланованих цілей i заходів, щодо захисту національних інтересів України, з бюджетним процесом у державі; недостатній рівень міжвідомчої взаємодії, як між складовими сектору безпеки та оборони (далі СБО), так і 3 органами державної влади під час визначення цілей i завдань 3 оборони, плануванні застосування сил i засобів; недостатнє використання досвіду провідних країн світу щодо оборонного планування, що грунтується на спроможностях тощо. Це супроводжується нераціональним розподілом наявних державних ресурсів, плануванням їх розвитку та накопичення на середньо- та довгострокову перспективи, а отже i задовільним результатом оцінювання ходу виконання оборонних цільових програм.

Для визначення достатності та відповідності наявних оборонних ресурсів, а отже обгрунтування потреб i напрямів стратегічного розвитку складових СБО та планування їх довгострокової реалізації, періодично проводиться оцінювання якості виконання заходів оборонного планування у формі комплексного огляду СБО. Головною метою цього заходу $\epsilon$ перевірка стану та готовності його сил $\mathrm{i}$ засобів виконувати завдання з оборони держави за певних умов та відповідного ресурсного забезпечення, на основі чого сформувати підгрунтя для подальшого планування їх утримання та розвитку. На жаль, як показує аналіз попередніх оглядових заходів [6-8], які проводились з 2003 року, в цьому напрямі існує також низка недоліків, серед яких є: незбалансованість державного та військового управління СБО; низький рівень міжвідомчої 
взаємодії, а отже і невідповідність розподілу складових СБО для забезпечення виконання заходів з безпеки та оборони країни; неякісна підготовка та організація процесу комплексного огляду через відсутність належного методичного підгрунтя; нечіткість розумінням перспективної організаційної структури СБО, ïi комплексного використання та управління нею під час виникнення загрозливих ситуацій i можливих сценаріїв подальшого їх розвитку тощо.

Проаналізовані відкриті джерела, які розкривають виявлені проблемні питання, не розглядають важливість врахування життєвого циклу зразків озброєння та військової техніки, як у процесі оцінювання спроможностей під час оборонного огляду, так i безпосередньо під час оборонного планування, адже цей процес $\epsilon$ достатньо складним і потребує значних капіталовкладень, технологічних спроможностей та часових обмежень, які мають враховуватись під час довгострокового планування.

Узагальнюючи аналіз, можна дійти висновку, що результати оборонного огляду як інформаційне підгрунтя для планування, в тому числі технічної складової сил оборони, так і процес оборонного планування на основі спроможностей, який реалізує поетапне вирішення виявлених прогалин в обороноздатності держави, без врахування життєвого циклу зразків ОВТ можуть бути не достатньо реалістичними та ефективними, що в гіршому випадку не забезпечить надійного виконання завдань з оборони країни.

Вирішення зазначених проблемних питань може бути реалізовано завдяки впровадженню найкращих світових практик, концептуальних підходів і стандартів, які складають основу для системи оборонного планування на основі спроможностей в країнах-членах Північноатлантичного альянсу.

Мета статті - обгрунтування необхідності врахування під час оборонного огляду та процесу оборонного планування, побудованого на основі спроможностей, життєвого циклу перспективного зразка озброєння та військової техніки, 3 метою раціонального прогнозування та розподілу оборонних ресурсів на середньо- та довгострокову перспективи для своєчасного забезпечення надійного рівня обороноздатності держави.

Виклад основног 32003 року, після тривалого застою, пов'язаного із розпадом Радянського Союзу, Україна розпочала перші кроки щодо реформування вже власних незалежних українських збройних сил, для виведення їх на рівень, який би відповідав сучасним викликам безпекового середовища i забезпечував надійну обороноздатність держави, враховуючи реальні та перспективні воєннополітичні відносини країни, а також можливий розвиток національних відносин із країнами-сусідами.

Підгрунтям для реалізації реформування та розвитку збройних сил $\epsilon$ оборонне планування 3 тісною прив'язкою до ресурсних можливостей держави, основними завданнями якого відповідно до [9], є:

оцінювання стану та готовності сил оборони до виконання завдань 3 оборони держави, а також результатів виконання заходів щодо їх розвитку за попередній період;

визначення засад, цілей i завдань державної політики у сфері оборони, пріоритетів і напрямів розвитку сил оборони, враховуючи реальні та потенційні загрози та фінансово-економічні можливості держави; встановлення вимог до структури i чисельності сил оборони, а також показників ix забезпечення озброєнням i військовою технікою (далі ОВТ), матеріальними ресурсами тощо;

визначення видатків Державного бюджету України на потреби оборони;

формування сукупності державних оборонних замовлень на задоволення потреб у перспективних (модернізованих) ОВТ, широкого спектру послуг оборонного значення, виконання науково дослідних i дослідно-конструкторських робіт (далі НДДКР);

формування заходів щодо мобілізаційної підготовки.

Отже, як бачимо, деякі завдання оборонного планування, iз зазначеного переліку, мають тісний зв'язок з управлінням життєвим циклом (далі ЖЦ) зразків ОВТ, у частині, що стосується визначення показників забезпеченості відповідними зразками і їх якісного стану, формування видатків на їх подальше утримання та розвиток, а також програмно-цільова реалізація задоволення потреб у перспективних (модернізованих) зразках ОВТ.

Для усвідомлення важливості такого зв'язку розглянемо процес оборонного планування на онові спроможностей, реалізованого в провідних країнах світу, та 
покажемо яким чином організовується його зв'язок із ЖЦ зразків ОВТ.

Для оцінювання стану та готовності складових сил оборони, на регулярній основі в розвинутих країнах, які входять до складу Північноатлантичного альянсу (далі НАТО), проводиться огляд результатів виконання заходів 4-річного циклу оборонного планування NDPP (NATO Defense Planning Process).

Як зазначено в роботі [6], весь цикл оборонного планування NDPP включає в себе 5 етапів (рис. 1), загальною метою виконання яких $є$ узгодження національних оборонних програм із цілями та завданнями Альянсу щодо набуття необхідного рівня колективної безпеки та оборони. Іншими словами, NDPP це процес визначення кількісних i якісних показників спроможностей, якими, відповідно до визначеного рівня амбіцій коаліції, мають володіти складові коаліційних сил на випадок виявлення загроз або їх імовірного виникнення у довгостроковій перспективі. До того ж сили та засоби НАТО мають бути спроможними одночасно виконувати дві великомасштабні та шість дрібних операцій.

Кожен з етапів оборонного планування в НАТО охоплює певні заходи, які у логічній i взаємозалежній послідовності забезпечують створення необхідних i розвиток існуючих спроможностей, які мають бути розподілені між країнами-членами, враховуючи їх національний потенціал $\mathrm{i}$ наявні локальні спроможності. Усі заходи планування перебувають під постійним контролем відповідних органів, які в разі потреби можуть здійснити перерозподіл ресурсів на більш пріоритетні напрями. У разі виявлення непотрібних спроможностей, їх зазвичай вилучають із загального списку необхідних спроможностей, вивільнюючи тим самим кошти та ресурси на забезпечення утримання, розвиток та створення тих спроможностей, які відповідають визначеному рівню амбіцій.

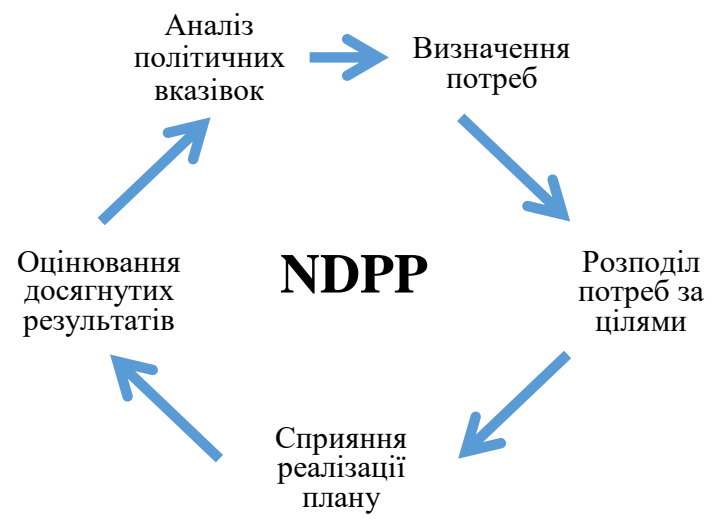

Рис.1. Етапи циклу оборонного планування, реалізованого в НАТО

Для планування будівництва та застосування збройних сил, під час оборонного планування НАТО відповідною системою Joint Capabilities Integration and Development System (JCIDS) виконується низка заходів, які пов'язані з аналізом стану наявних спроможностей 3 метою виявлення в них так званих “прогалин”, подальше затвердження та визначення пріоритетів їх вирішення для забезпечення відповідності обороноздатності коаліційних сил визначеним вимогам.

Цей процес реалізовується на основі детальної оцінки місій, функцій i завдань НАТО у контексті загроз і стану навколишнього середовища, щоб ідентифікувати та кількісно визначити вимоги до спроможності. Отже в розумінні НАТО вимоги до спроможності є не що інше як міри ефективності, які формуються у такому форматі: завдання, умови та стандарт. Вони є певним інструментом вирішення існуючих або імовірних перспективних загроз, на цім більшої уваги приділяють не розмірам витрат на їх реалізацію, а тому, що потрібно зробити (тобто метриці) і до якого рівня має пройти реалізація.

Потім визначені вимоги до спроможностей порівнюються 3 існуючими та запрограмованими рішеннями щодо спроможності в рамках об'єднаних сил для виявлення потенційних прогалин у цих спроможностях. Прогалини, які являють собою неприйнятний ризик, можуть потребувати нових (модифікованих) матеріальних (ОВТ) чи нематеріальних (редагування або створення нових директивних, нормотворчих документів, зміна процедур чи концепцій тощо) рішень, а також використання додаткових ресурсів.

Порівняно 3 типовим набором стадій ЖЦ ОВТ (рис. 3) у нашій країні, в країнахчленах НАТО, відповідно до [11], додатково існує така стадія, як “перед-концепція" (pre- 
concept stage), однією з вимог якої, окрім обгрунтування основних цілей івимог до перспективного зразка ОВТ, є визначення можливих ризиків при створенні виробу, базуючись на прогнозних показниках оборонного бюджету, технологічних можливостях і наукового заділу. Як бачимо, цю стадію ЖЦ використовують саме як сполучення ОПОС i цільових програм створення зразків ОВТ. Це підтверджує факт прямого зв'язку життєвого циклу 3 процесом оборонного планування на основі спроможностей і подальшої його реалізації програмно-цільовим методом на середньо- та довгострокову перспективи. Отже, як показує досвід розвинутих країн, під час ОПОС $€$ необхідність враховувати ЖЦ зразків ОВТ і їх актуальний стан перебування на відповідних його стадіях, для подальшого прогнозування ризиків можливого невиконання спланованих оборонних завдань 3 причин невідповідності технічної складової носія спроможності.

Для підкреслення важливості врахування ЖЦ перспективного зразка ОВТ, як складного довготривалого процесу, розглянемо його складові та стани перебування типових зразків ОВТ.

За результатами порівняння наявних i визначених необхідних спроможностей, формується потреба у плануванні заходів щодо їх подальшого утримання, за умови задовільного рівня наявних спроможностей. У разі ж незначної невідповідності наявних спроможностей амбіційним потребам, плануються заходи щодо їх подальшого розвитку. Якщо результати порівняльного аналізу констатували вкрай критичний стан існуючих спроможностей, що призводить до неможливості вирішення перспективного завдання наявним складом сил i засобів, плануються заходи щодо створення нових спроможностей i $і$ іх носіїв (військових формувань). Типовий носій спроможності включає зазвичай як технічну складову (OBT), так і особовий склад (органи управління та підпорядковані їм підрозділи). Отже під час визначення потреби в розвитку або створенні нових носіїв спроможностей, які реалізують необхідну спроможність, необхідно розрізняти та планувати окремо фінансові ресурси для реалізації розвитку або створення окремо технічної складової носія спроможності та окремо людських ресурсів, як іншої складової цього носія.

Зазвичай на утримання, розвиток i створення ОВТ, витрачають близько $60 \%$ від загальної сукупності оборонного бюджету, що потребує більшої уваги саме у процесі оцінювання технічної складової носіїв спроможності під час оборонного огляду, який формує вихідну інформаційну базу для ОПОС. Підтвердженням цієї необхідності $є$ отримані консультативні поради під час неодноразових зустрічей спільної робочої групи 3 консультативних питань оборонного менеджменту НАТО, на яких неодноразово наголошувалось, що в процесі оборонного планування значну увагу приділяють саме ОВТ, оскільки воно потребує більшої частки їх бюджету.

Відповідно до [10], розробленого 3 урахуванням стандартів НАТО, життєвий цикл (далі ЖЦ) являє собою еволюцію системи, виробу, послуги, проєкту або іншого створеного об'єкта у часі, починаючи від його задуму і закінчуючи його вилученням 3 обігу (утилізацією). Типовий ЖЦ виробу ОВТ включає в себе декілька стадій i етапів, кількість яких залежить від складності зразка, який створюється, та умов (обмежень) його реалізації, які випливають із наявних фінансових, технологічних можливостей i часових обмежень країни (рис. 2).

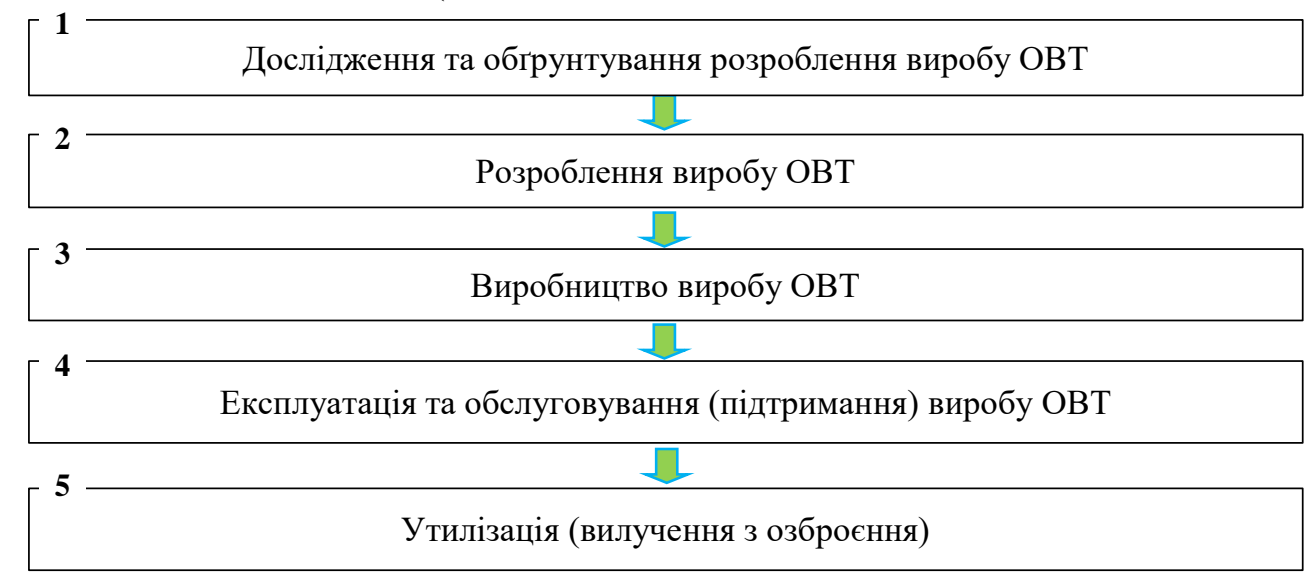

Рис. 2. Типові стадії життєвого циклу виробу ОВТ 
Стадія “дослідження та обтрунтування розроблення виробу ОВТ" може включати проведення таких етапів, як виконання аванпроєкту (тільки під час створення складних систем ОВТ, які потребують значних наукових, фінансових i часових витрат, а отже і відповідного рівня технікоекономічного обгрунтування доцільності створення цього виробу) та проведення науково-дослідної роботи, основною метою якої $\epsilon$ розроблення проєкту тактикотехнічного завдання (технічного завдання) ТТЗ (Т3) на дослідно-конструкторську роботу (ДКР) щодо перспективного розроблення нового або модернізації вже існуючого зразка ОВТ. На другій стадї ДКР, за результатами якої розробляється готовий комплект робочої конструкторської та технологічної документацій для поставлення на виробництво перспективного зразка ОВТ та його складових частин (підсистем).

Стадія “виробництва" проводиться зазвичай у два етапи, під час яких організовується постановка виробу ОВТ на виробництво, тобто технологічна підготовка та навчання персоналу підприємств обороннопромислового комплексу до виробництва цього виробу, а також безпосереднє серійне виробництво зразка (його складових) 3 подальшим постачанням у війська, в разі успішно проведених державних випробувань. У разі відсутності або неефективності наявних технологій для розроблення чи виготовлення окремих підсистем складного зразка ОВТ (літака, танку, корабля, реактивної системи залпового вогню тощо), такі складові можуть закупатися у сторонніх організаціях країни або закордоном. За умов обмеженості у фінансових ресурсах, можуть використовуватись вже наявні сумісні комплектуючі, але 3 гіршими від бажаних еталонних характеристик (морально застарілі підсистеми), що призводить до заниження очікуваного рівня технічної досконалості зразка, що розроблюється.

Під час експлуатаиії виробу OBT, проводяться планові та позапланові ремонтно- відновлювальні роботи, основною метою яких $\epsilon$ підтримання зразка у справному та боєздатному стані, за допомогою відновлення його ресурсу до норм, визначених $\mathrm{y}$ технологічній документації відповідного зразка. Як окрему стадію, виділяють “капітальний ремонт”, оскільки зразок ОВТ виводиться 3 експлуатації на період, необхідний для відновлення встановленого ресурсного рівня (близького до встановленого). У разі досягнення зразком OBT свого граничного періоду експлуатації, обгрунтовується фінансова та технологічна доцільність його подальшого відновлення. За негативними результатами його оцінювання, вживаються відповідні заходи щодо подальшої утилізаиії (знаття з озброєння) цього зразка ОВТ, 3 можливістю його використання у навчальних, невійськових цілях або деструкції.

Отже, з огляду на аналіз, видно, що ЖЦ $€$ дійсно складний, ієрархічний процес, кожна стадія та етапи якого потребують значних часових, фінансових, технологічних і людиногодинних витрат для досягнення необхідного ефекту. Навіть у країні із надрозвинутим потенціалом виробництва ОВТ, час, витрачений на створення нового зразка, вимірюється 10-12 роками, а 3 подальшою підготовкою та освоєнням серійного виробництва він може сягати $15-20$ років. Це підкреслює необхідність враховувати особливості життєвого циклу створення перспективних зразків ОВТ під час ОПОС на середньо- та довгострокову перспективи, для завчасного планування початку його стадій для своєчасного переоснащення сучасним OBT військових формувань 3С та інших складових сил оборони.

Воєнно-економічний

аналіз ефективності зразків ОВТ полягає в зіставленні отриманого бойового ефекту 3 матеріальними витратами на досягнення такого ефекту. Візуально це відображено на графіку залежності ефекту/вартості від стадії ЖЦ, на яких перебуває зразок ОВТ.

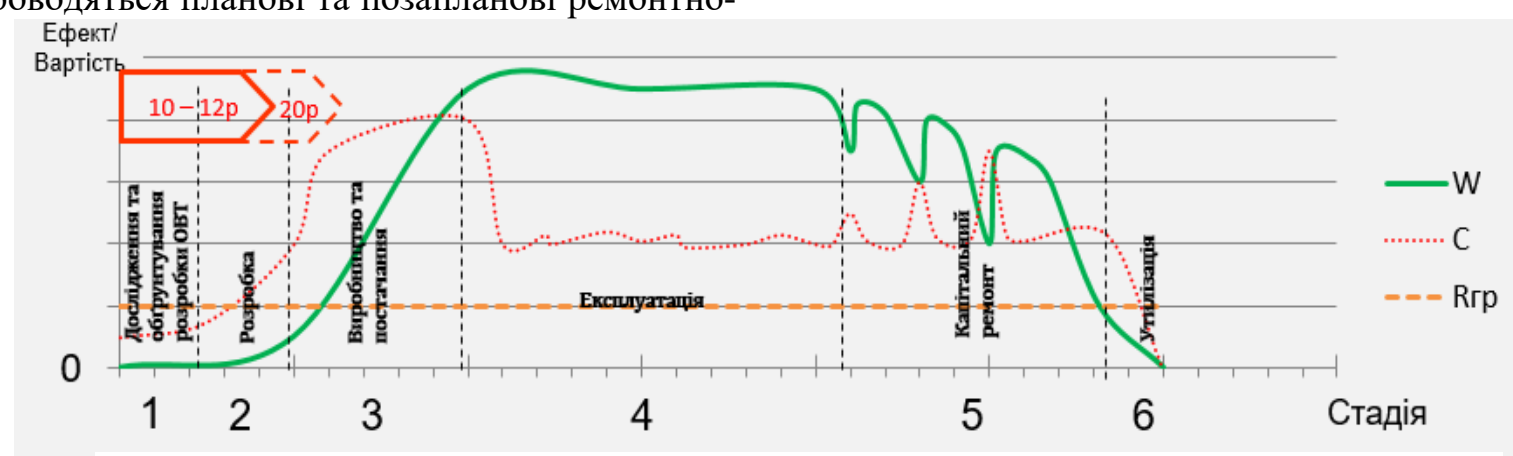

Рис. 3. Типова залежність витрат та ефекту від стадії життсвого циклу виробу ОВТ 
Як показано на графіку (рис. 3), витрати фінансових ресурсів $C$ на реалізацію стадій ЖЦ та отриманий від цього ефект $W €$ не рівномірними, до того ж на початкових стадіях (розроблення, виробництво та постачання) вартість та ефект значно зростають, що характеризує вже отримання користі від розробленого дослідного зразка та проведення відповідних випробувань на всіх його стадіях. Це дає обгрунтування щодо відповідності вимог до зразка з врахуванням досягнутого в країні рівня науки, техніки та виробництва, результатів досліджень 3 питань протидії засобам противника у разі виконання зразком своїх функцій. Під час стадії експлуатації ефективність зразка ОВТ досягає свого максимального значення та має лише незначні коливання, залежно від поточного стану та особливостей його експлуатації, до того ж витрати зменшуються до рівня, необхідного для його щорічного утримання. На стадії капітального ремонту ефект вже “пилко-подібно" спадає через виведення його із стадії експлуатації на час ремонту та поверненням його до строю, зі зростанням фінансових витрат на капітальне відновлення його ресурсів. Урешті-решт настає такий момент, коли відновлення ресурсів, які дійшли гранично допустимого рівня $R_{\text {гр }}$, $\epsilon$ недоцільним, тобто затрачені кошти не відповідають отриманому ефекту. Це змушує приймати відповідні рішення щодо переводу відповідного зразка в стадію утилізації, тим самим вивільнюючи кошти на його утримання для потреб модернізації чи створення нових перспективних зразків.

Отже у процесі оцінювання ОВТ наявних носіїв спроможностей та під час формування потреб щодо перспективного переоснащення більш сучасними та ефективними зразками ОВТ, які б відповідали сучасним науково-технічним досягненням та безпековим викликам, необхідно враховувати складність усіх процесів ЖЦ, часові та витратні особливості кожної його стадії, що є вкрай необхідним під час ОПОС і відповідно під час формування прогнозних показників державних видатків на оборонну сферу на довгострокову перспективу.

Таким чином, неврахування особливостей і складності ЖЦ могло бути й однією 3 причин негативних результатів реалізації затвердженого у 2004 році Стратегічного оборонного бюлетеня, відповідно до [6], цілями та завданнями якого були заплановані значні кроки в оборонній сфері, пов'язані з переоснащенням військових формувань новими сучасними зразками озброєння та військової техніки, відновлення спроможності вітчизняного обороннопромислового комплексу, шляхом упровадження новітніх технологій завдяки співпраці 3 державами-партнерами та впровадження власних замкнених циклів створення перспективних ОВТ, підвищення ефективності бюджетної політики у сферах національної безпеки і оборони України тощо, враховуючи до того ж фінансово-економічні можливості країни. На жаль, частина заходів оборонної реформи була реалізована не повністю, а іноді і взагалі на досить низькому piвні. Це стосується i планового переоснащення Збройних Сил України сучасними (модернізованими) зразками ОВТ.

Висновки. Отже, як було висвітлено у статті, на сьогодні існують проблемні питання переходу на оборонне планування на основі спроможностей. Це виявляється в питаннях якісної оцінки рівня спроможностей під час оборонного огляду, результати якого формують базову інформаційну основу для реалізації ОПОС. Як зазначалося, вагому частку бюджетних видатків в оборонну сферу виділяється саме на створення, утримання та розвиток зразків ОВТ, як технічної складової носія спроможності, що оцінюється. Складність створення та утримання зразків OBT обгрунтовується саме стадіями його життєвого циклу, які характеризуються значним рівнем наукоємності під час обгрунтування його створення, значними часовими витратами часу та фінансуванням на кожному етапі відповідних стадій. Отже можна стверджувати, що між процесом ОПОС і життевим циклом ОВТ існує досить тісна кореляція. Чим якісніше та своєчасно визначати потреби в нових (модернізованих) зразках ОВТ, під час оборонного огляду, тим швидше будуть сплановані відповідні стадії життєвого циклу перспективного зразка та необхідні для цього Бюджетні ресурси, і тим ефективніше будуть реалізовані цілі та завдання ОПОС на середньо- та довгострокову перспективи, що знайде відображення в Державній цільовій оборонній програмі розвитку озброєння та військової техніки збройних сил.

Подальші дослідження доцільно зосередити на аналізі існуючих методів оцінювання технічної складової носіїв спроможностей i розробленні методу прогнозування основних параметрів типового 
життєвого циклу зразка ОВТ, використовуючи метод регресійного аналізу, для підвищення якості оборонного планування на основі спроможностей, який би гармоніював із принципами та стандартами країн-членів HATO.

\section{СПИСОК ВИКОРИСТАНОЇ ЛІТЕРАТУРИ}

1. Руснак I. C., Петренко А. Г., Я Яковенко А. В., Романюк І. М., Кохно В. Д. Оборонне планування на основі спроможностей: особливості та перспективи впровадження. Наука і оборона. 2017. № 2. С. 3-10. DOI: https://doi.org/10.33099/2618-1614-2017-0-2-3-10.

2. Ворович Б. О., Наливайко А. Д., Поляєв А. I. Проблемні питання щодо удосконалення системи оборонного планування в силах оборони України. Збірник наукових праць Центру воєнно-стратегічних досліджень Національного університету оборони Украйни імені Івана Черняховського. Київ, 2017. № 2 (60). C. 30-33. DOI: https://doi.org/10.33099/23042745/2017-2-60/30-33.

3. Чепков I. Б., Сотник В. В., Борохвостов I. В., Бондарчук М. В., Білокур М.О. Порівняльний аналіз систем оборонного планування в США та в Україні. Озброєння та військова техніка. Київ, 2019. № 3 (23). C. 3-15. DOI: https://doi.org/1034169/24140651.2019.3(23).3-15.

4. Романченко I. C., Богданович В. Ю., Дєнєжкін М. М., Крикун П. М. Стан і перспективи розвитку системи оборонного планування в Збройних Силах України. Наука і оборона. 2017. № 1. С. 25-30.
DOI: https://doi.org/10.33099/2618-1614-2017-0-1-2530.

5. Слюсар В. І., Кулагін К. К. Особливості процесу оборонного планування НАТО. Наука $i$ техніка Повітряних Сил Збройних Сил України. Харків, 2019. № 3 (36). C. 47-59. DOI: https://doi.org/10.30748/ nitps.2019.36.06

6. Наливайко А. Д., Поляєв А. І., Сівоха І. М. Генезис та розвиток оборонного планування в Україні. Сучасні інформаційні технології у сфері безпеки та оборони. Київ, 2017. № 2 (29). С.138-143. DOI: https://doi.org/10.33099/2311-7249/2017-29-2-138-143.

7. Оборонний огляд: український вимір 2014-2018 : монографія / Ф. В. Саганюк та ін. Київ : НУОУ, 2019. $196 \mathrm{c}$.

8. Дєнєжкін М. М., Крикун П. М., Р Рунак I. С. Проблеми проведення комплексного огляду сектору безпеки та оборони України: погляди на його організацію та вирішення завдань. Наука $і$ оборона. 2014. № 4. C. 3-10.

9. Про організацію оборонного планування : Закон України від 18.11.2004 p. № 2198-IV. URL: http://zakon5.rada.gov.ua/laws/show/2198-15 (дата звернення: 10.09.2020).

10. ДСТУ В-П 15.004:2020. Система розроблення і поставлення на виробництво озброєння та військової техніки. Стадії життєвого циклу озброєння та військової техніки.

11. AAP-20:2015 NATO Programme Management Framework (NATO Life Cycle Model).

Стаття надійшла до редакційної колегії 11.12.2020

\section{Grounding of consideration of the life cycle of weapons and military equipment in defense planning based on capabilities}

\section{Annotation}

An analysis of open sources and online publications regarding strategic planning, in particular the technical component of the defense forces, showed that the issue of life cycle was left out of consideration of samples of armaments and military equipment, both when assessing capabilities in the defense review and during medium and long term defense planning. The results of the defense review as an information basis for capability-based defense planning, without considering the life cycle of samples of armaments and military equipment, may not be realistic enough, which in the worst case may not ensure reliable implementation of national defense tasks.

The purpose of the article is to substantiate the need considering during the defense review and defense planning process, based on capabilities, the life cycle of a promising model of armaments and military equipment to rationally forecast and allocate defense resources to ensure a reliable level of defense.

A typical life cycle of a product of armaments and military equipment may include several stages. The number of stages depends on the complexity of the type of sample being created and the conditions of its implementation, which follow from the following constraints: the financial condition of the country, technological capabilities of production and time indicators.

There is a pre-concept stage in NATO countries, one of the tasks of the stage in addition to substantiating the main goals and requirements for a promising model of armaments and military equipment, is identifying of possible risks in product development based on: forecast indicators of defense budget, technological capabilities and scientific potential.

Qualitative and timely determination of the need for new (modernized) models of armaments and military equipment during the defense review is the basis for ordering the necessary budget resources and setting certain tasks for the medium and long term, which in turn will find its place in the State Targeted Defense Arms and Development Program of the Armed Forces of Ukraine.

Keywords: capability-based defense planning; ability; capacity carriers; life cycle stages; sample of weapons and military equipment. 